\title{
Pengaruh rendaman cuka (asam asetat) terhadap kekerasan amalgam
}

\author{
${ }^{1}$ Rigel N. V. Taneh \\ ${ }^{2}$ Michael A. Leman \\ ${ }^{2}$ Johanna A. Khoman
}

\author{
${ }^{1}$ Kandidat Skripsi Program Studi Pendidikan Dokter Gigi Fakultas Kedokteran \\ ${ }^{2}$ Program Studi Pendidikan Dokter Gigi Fakultas Kedokteran \\ Universitas Sam Ratulangi Manado \\ E-mail: fxrnvt@gmail.com
}

\begin{abstract}
Amalgam filling has been used since the 19th century. The hardness of a filling material in the mouth may be affected by acidic drinks or foods. One of the foods normally consumed by the Indonesian is acidic due to its vinegar content. This study was aimed to determine the effect of vinegar on the change of amalgam hardness. This was a laboratory experimental study with a post test only control group design. There were 30 samples of amalgam plates with a diameter of $5 \mathrm{~mm}$ and $2 \mathrm{~mm}$ of thickness. The samples were divided into two groups with three different immersion times, as follows: 5, 10, and 20 minutes. After immersion, the samples' hardness was measured by using the Micro Vickers Hardness Tester. Data normality was tested with Shapiro-Wilk test, then the data were statistically analyzed with independent sample t-test. The results showed a significant effect of vinegar immersion on changes in amalgam hardness $(P<0.05)$. Conclusion: Vinegar immersion affected the hardness of amalgam.
\end{abstract}

Keywords: amalgam, vinegar, surface hardness

\begin{abstract}
Abstrak: Amalgam merupakan bahan tumpatan yang digunakan sejak abad ke-19. Sifat keras suatu bahan tumpatan di dalam rongga mulut dapat dipengaruhi oleh minuman asam atau makanan yang dikonsumsi. Salah satu makanan yang biasanya dikonsumsi oleh orang Indonesia bersifat asam dan mengandung bahan cuka. Penelitian ini bertujuan untuk mengetahui pengaruh rendaman cuka terhadap perubahan kekerasan amalgam. Jenis penelitian ialah eksperimental laboratorik dengan desain post test only control group. Sampel penelitian ini ialah lempeng amalgam berbentuk lingkaran dengan ukuran diameter $5 \mathrm{~mm}$ dan tinggi 2 mm sebanyak 30 buah. Sampel dibagi menjadi dua kelompok dengan tiga durasi waktu perendaman yang berbeda yaitu 5,10 , dan 20 menit. Setelah perendaman, sampel diukur nilai kekerasannya menggunakan Micro Vickers Hardness Tester, kemudian dilakukan uji normalitas data menggunakan uji Shapiro-Wilk. Data dianalisis secara statistik dengan menggunakan uji independent sample t-test. Hasil penelitian menunjukkan adanya pengaruh bermakna dari perendaman cuka terhadap perubahan kekerasan amalgam $(P<0.05)$.
\end{abstract}

Simpulan: Perendaman cuka memengaruhi kekerasan amalgam.

Kata kunci: amalgam, cuka, kekerasan permukaan

Karies gigi merupakan masalah kesehatan yang masih banyak ditemukan di negara maju maupun berkembang. ${ }^{1}$ Perawatan pada gigi yang mengalami karies tergantung pada jaringan yang tersisa, permukaan yang terlibat, jenis bahan yang sesuai, serta estetik yang diharapkan. ${ }^{2}$ Untuk mengembalikan fungsi oral, estetis, kesehatan, kenyamanan pasien, serta mencegah proses berkembangnya penyakit dan merestorasi bagian gigi yang sudah hilang, dibutuhkan bahan restorasi. ${ }^{3}$ Saat 
ini, terdapat beberapa macam bahan restorasi yang digunakan oleh dokter gigi, seperti amalgam, glass ionomer cement, dan resin komposit. Hal ini memberi kesempatan bagi pasien maupun dokter gigi untuk memilih bahan tumpatan yang diinginkan berdasarkan pertimbanganpertimbangan tertentu dari dokter gigi. ${ }^{4}$

Amalgam merupakan bahan tumpatan yang digunakan sejak abad ke-19. ${ }^{5}$ Amalgam merupakan bahan restorasi yang paling banyak digunakan dibandingkan bahan restorasi lainnya. Amalgam merupakan campuran dari dua atau beberapa logam (alloy) di antaranya merkuri $(\mathrm{Hg})$, perak $(\mathrm{Ag})$, timah $(\mathrm{Sn})$, dan tembaga $(\mathrm{Cu})$. Bahan tumpatan ini merupakan pilihan untuk restorasi gigi posterior karena sifatnya kuat dibandingkan bahan restorasi lain. Karakteristik amalgam yaitu memiliki ketahanan dalam jangka waktu yang panjang, mudah dimanipulasi,dan harganya relatif murah. ${ }^{6}$

Amalgam memiliki kekurangan yaitu bersifat toksik. Kandungan merkuri $(\mathrm{Hg})$ dalam amalgam sangat berbahaya bagi kesehatan organ tubuh manusia, tetapi badan kesehatan yang berwenang seperti World Health Organization (WHO) dan American Dental Association (ADA) menyatakan bahwa amalgam masih aman dan efektif jika dimanipulasi sesuai dengan prosedur. $^{7}$ Hingga saat ini penggunaan bahan tambal amalgam masih banyak digunakan di kalangan masyarakat luas karena biaya yang relatif murah dibanding bahan tambal lainnya dan ketahanan penggunaan tergolong cukup lama.

Sifat keras suatu bahan tumpatan di dalam rongga mulut dapat dipengaruhi oleh makanan atau minuman yang dikonsumsi. Salah satu makanan yang biasa dikonsumsi oleh orang Indonesia bersifat asam yang mengandung bahan cuka. Bahan ini telah dikenal manusia sejak zaman dahulu dan dihasilkan oleh berbagai bakteri penghasil asam asetat. Asam ini merupakan produk sampingan dari pembuatan bir atau anggur. ${ }^{8,9}$ Asam asetat dapat dibuat dari substrat yang mengandung etanol dan dapat diperoleh dari berbagai macam bahan seperti buah-buahan, kulit nenas, bubuk kopi, dan air kelapa. Pada abad III SM, filsuf Yunani kuno menjelaskan bahwa cuka bereaksi dengan logam-logam membentuk berbagai zat warna, misalnya timbal putih (timbal karbonat), dan verdigris, yaitu suatu zat hijau campuran dari garam-garam tembaga dan mengandung tembaga asetat. ${ }^{10}$

Cuka biasanya mengandung 4-18\% massa asam asetat. Cuka digunakan langsung sebagai bumbu dan dalam pengawetan sayuran ataupun makanan lain. Cuka cenderung menjadi lebih encer $(4 \%$ sampai $8 \%$ asam asetat), sedangkan makanan acar komersial menggunakan larutan yang lebih pekat. ${ }^{11}$

Penggunaan asam asetat sebagai pereaksi kimia juga sudah dimulai sejak lama. Provinsi Sulawesi Utara merupakan daerah yang terkenal dengan berbagai macam makanan tradisionalnya, antara lain gohu. Makanan ini identik dengan buah pepaya yang dicampur berbagai macam bahan makanan dan memiliki kuah yang bersifat asam karena mengandung asam cuka yang mudah didapat di pasaran.

Hasil penelitian Tanga et al. ${ }^{12}$ terhadap perendaman bahan tumpatan glass ionomer cement (GIC) dalam larutan asam asetat menunjukkan waktu perendaman tidak berpengaruh secara bermakna terhadap bahan tumpatan GIC. Penelitian ini bertujuan untuk mengetahui pengaruh rendaman cuka terhadap kekerasan amalgam.

\section{BAHAN DAN METODE PENELITIAN}

Jenis penelitian ini ialah eksperimental laboratorik dengan post-test only control group design. Penelitian ini dilaksanakan di Laboratorium Teknik Mesin Fakultas Teknik Universitas Sam Ratulangi Manado pada bulan Desember 2016.

Sampel penelitian ialah lempeng amalgam yang berbentuk lingkaran dengan ukuran diameter $5 \mathrm{~mm}$ dan tinggi $2 \mathrm{~mm}$ sebanyak 30 buah. Sampel dibagi menjadi dua kelompok. Kelompok I terdiri dari 15 amalgam untuk perendaman dengan saliva buatan dan kelompok II terdiri dari 15 amalgam yang direndam ke dalam larutan 
cuka dan saliva buatan dengan perbandingan 1:1. Setiap sampel diberi tanda nomor urut untuk setiap kelompok. Perendaman kelompok I dan II dilakukan pada berbagai durasi waktu yang didapatkan setelah dilakukan pra penelitian, yaitu 5 sampel amalgam dengan durasi 5 menit, 5 sampel amalgam dengan durasi 10 menit, dan 5 sampel amalgam dengan durasi 20 menit. Setiap kelompok dalam berbagai durasi waktu diukur kekerasannya menggunakan alat Micro Vickers Hardness Tester dengan satuan VHN.

Data hasil penelitian dianalisis dengan uji independent sample t-test.

\section{HASIL PENELITIAN}

Tabel 1 memperlihatkan hasil penghitungan kekerasan amalgam terhadap saliva dan cuka dari kelompok kontrol dan kelompok perlakuan.

Tabel 2 menunjukkan hasil uji statistik dengan uji independent sample t-test pada hasil pengukuran kekerasan amalgam terhadap saliva dan cuka dari kelompok kontrol dan kelompok perlakuan. Hasil uji statistik mendapatkan pada kelompok kontrol dengan lama perendaman 5 menit, 10 menit, dan 20 menit dengan nilai $P=$ 0,000; demikian pula pada kelompok perlakuan dengan lama perendaman 5 menit, 10 menit dan 20 menit dengan nilai $P=0,000$.

Tabel 1. Hasil penghitungan kekerasan amalgam terhadap saliva dan cuka sebagai kelompok kontrol dan kelompok perlakuan

\begin{tabular}{ccccccc}
\hline \multirow{2}{*}{ Waktu } & \multicolumn{7}{c}{ Kelompok kontrol (saliva)B } \\
& 1 & 2 & 3 & 4 & 5 & Rerata \pm S \\
\hline 5 menit & 102,7 & 104,1 & 101,2 & 103,6 & 100,8 & $102,48 \pm 1,44$ \\
10 menit & 99,4 & 96,2 & 95,8 & 98,4 & 96,8 & $97,32 \pm 1,52$ \\
20 menit & 94,5 & 88,8 & 92,4 & 95,7 & 89,2 & $92,12 \pm 3,08$ \\
\hline \multirow{2}{*}{ Waktu } & 1 & \multicolumn{7}{c}{ Kelompok perlakuan (cuka+saliva) } \\
& \multicolumn{7}{c}{5} & 3 & 4 & 5 & Rerata \pm SB \\
\hline 5 menit & 80,5 & 79,5 & 79,2 & 81,2 & 79,8 & $80,04 \pm 0,80$ \\
10 menit & 73,6 & 75,1 & 73,6 & 75,7 & 76,0 & $74,80 \pm 1,14$ \\
20 menit & 67,9 & 68,4 & 68,6 & 69,5 & 67,3 & $68,54 \pm 1,20$ \\
\hline
\end{tabular}

SB: simpang baku

Tabel 2. Hasil statistik pengukuran kekerasan amalgam dengan uji independent sample t-test

\begin{tabular}{ccccccc}
\hline \multirow{2}{*}{ Waktu } & \multicolumn{3}{c}{ Kelompok kontrol (saliva) } & \multicolumn{3}{c}{$\begin{array}{c}\text { Kelompok perlakuan } \\
\text { (cuka+saliva) }\end{array}$} \\
& $\mathrm{n}$ & Rerata \pm S.b & $\mathrm{P}(<0,05)$ & $\mathrm{n}$ & Rerata \pm SB & $P(<0,05)$ \\
\hline 5 menit & 5 & $102,48 \pm 1,44$ & 0,000 & 5 & $80,04 \pm 0,80$ & 0,000 \\
10 menit & 5 & $97,32 \pm 1,52$ & 0,000 & 5 & $74,80 \pm 1,14$ & 0,000 \\
20 menit & 5 & $92,12 \pm 3,08$ & 0,000 & 5 & $68,54 \pm 1,20$ & 0,000 \\
\hline
\end{tabular}

SB: simpang baku

\section{BAHASAN}

Pemilihan lama waktu perendaman 5 menit, 10 menit, dan 20 menit pada penelitian ini didasarkan dari hasil pra penelitian dengan cara menghabiskan satu porsi gohu yang dilakukan pada lima responden. Pengukuran uji kekerasan yang dilakukan ialah pengukuran kekerasan dengan cara mekanis statis. Pengukuran kekerasan ini dilakukan dengan metode Vickers. Metode tersebut dilakukan dengan cara indentasi, yaitu dengan menekan 
Taneh, Leman, Khoman: Pengaruh rendaman cuka (asam asetat) terhadap ...

benda yang tidak terdeformasi ke dalam permukaan sampel yang diuji kekerasannya sehingga terjadi suatu bekas penekanan (lekukan) yang kemudian dijadikan dasar untuk penilaian kekerasannya. ${ }^{13}$

Hasil penelitian menunjukkan terdapat penurunan kekerasan amalgam antara kelompok kontrol dan kelompok perlakuan pada waktu 5, 10, dan 20 menit. Komposisi yang terkandung dalam saliva buatan ialah asam karbonat, dinatrium hidrogen fosfat, natrium klorida, kalium klorida, kalsium klorida, dan magnesium klorida, sedangkan komposisi yang terkandung dalam cuka ialah asam amino, asam organik, sakarida, vitamin B1, dan vitamin B2. Penurunan kekerasan yang terjadi pada kelompok kontrol dan kelompok perlakuan disebabkan oleh kandungan asam lemah dari kedua kelompok tersebut. Penurunan kekerasan yang bermakna terjadi pada kelompok perlakuan. Hal ini disebabkan oleh $\mathrm{pH}$ yang rendah dari campuran cuka+saliva yaitu 2,1 yang bereaksi terhadap amalgam sehingga elektro negatif perlahan terlepas dan terjadi penurunan kekerasan amalgam. Hasil penelitian terlihat bahwa nilai $P$ pada masing-masing konsentrasi memiliki nilai kurang dari 0,05 berarti perendaman masing-masing sampel dengan rentang waktu 5, 10 dan 20 menit memiliki pengaruh terhadap kekerasan permukaan amalgam.

\section{SIMPULAN}

Terdapat pengaruh yang bermakna dari perendaman cuka dan saliva buatan terhadap kekerasan amalgam pada waktu 5 menit, 10 menit, dan 20 menit.

\section{SARAN}

Perlu penelitian lanjutan mengenai perubahan warna pada amalgam, partikelpartikel yang terlepas saat perendaman amalgam, dan foto bentuk perubahan permukaan pada amalgam.

Ucapan terima kasih disampaikan pada dr. Murniati Tiho, M. Kes, AIFO, drg. P. S. Anindita, Sp. Orto, serta semua pihak yang baik secara langsung maupun tidak langsung telah menumbuhkan ide atau gagasan dalam pemikiran penulis sehingga dapat menyelesaikan penulisan artikel ini.

\section{DAFTAR PUSTAKA}

1. Sondang P, Hamada T. Menuju Gigi dan Mulut Sehat. Medan: USU Press, 2008; p. 4.

2. Bakar A. Kedokteran Gigi Klinis (2nd ed). Yogyakarta: Quantum, 2012; p. 55, 579.

3. Baum, Phillips \& Lund Buku Ajar Ilmu Konservasi Gigi. Yuwono L, penerjemah. Jakarta: EGC, 1997; p. 1.

4. Rahmadhan AG. Serba-serbi Kesehatan Gigi dan Mulut. Jakarta: Bukune, 2010; p. 134-40.

5. Preben HB, Laszlo M, Palle $H$, Dorthe AB. Tambalan Amalgam Berbahaya untuk Kesehatan. Jakarta: EGC, 2008; p. 1-69.

6. Runi SB. Kondensasi pada dental amalgam. Medan: Fakultas Kedokteran Gigi Universitas Sumatera Utara; 2009.

7. Bambang I. Material restorasi direk kedokteran gigi saat ini. Jakarta: Fakultas Kedokteran Gigi Universitas Indonesia, 2004; p. 24-8.

8. Fessenden RJ, Fessenden JS. Dasar-dasar Kimia Organik. Jakarta: Erlangga, 1997; p. 399-404.

9. Lerner EKL, Lerner BW. The Gale encyclopedia of Science. (4th ed). Detroit. 2008. p. 15. Available from: URL: http://go.galegroup.com.

10. Irnia $\mathbf{N}$, Nur $\mathbf{H}$. Pembuatan asam asetat dari air kelapa secara fermentasi kontinyu menggunakan kolom biooksidasi. Malang: Fakultas Teknologi Pertanian Universitas Brawijaya, 2001; p. 51.

11. Bernthsen A, Sudborough JJ, Julio AS, Jacobo RP. Organic Chemistry (4th ed). London, 2002; p. 155.

12. Tanga A, Assa YA, Leman MA. Pengaruh waktu perendaman terhadap bahan tumpatan glass ionomer cement dalam larutan asam asetat. eG. 2016;4(1).

13. Viorel G, Toader A, George ID. The variation of the Vickers micro-hardness in the vicinity of the fracture surfaces at static loading. JESR. 2011;3(11):30-9. 